\title{
Aid, conflict and migration: the Canada-Sri Lanka connection
}

JENNIFER HYNDMAN

Department of Geography, Simon Fraser University, Burnaby BC V5A 1 S6 Canada (hyndman@sfu.ca)

This paper aims to disentangle patterns of aid, trade, conflict and migration between Canada and Sri Lanka, illustrating the surprisingly significant traffic between the two countries and exploring the significance and quality of these connections. International aid to Sri Lanka is closely related to the opening of markets to multinational investment beginning in 1977. This economic liberalisation overlaps with periods of conflict in Sri Lanka and of macroeconomic growth. The prosperity it has generated, however, has not benefited all social classes and ethnic groups. Accordingly, conflict in Sri Lanka has been characterised by uprisings led by unemployed youth, peaceful and violent protests of discrimination against Sri Lankan Tamils and militarised government reprisals to both. A long period of macroeconomic growth ended in the final quarter of 2001, after the bombing of commercial airliners at Sri Lanka's international airport. Geopolitical and geoeconomic conditions in Sri Lanka changed dramatically. In this context, Canada's International Development Agency (CIDA) and other aid agencies aspire to 'correct for conflict' and promote a democratic and peaceful Sri Lanka through peacebuilding and other aid measures. Militarised conflict over at least the past 20 years has generated massive human displacement both within and beyond the country's borders, spawning international migrants in search of asylum. In 1999, Sri Lanka was the leading source country of refugee claimants to Canada. Canada hosts the single largest Sri Lankan diaspora of any country. By examining the nexus of economic liberalisation and aid, I analyse its relation to conflict in Sri Lanka and migration to Canada.
Cette dissertation a pour but de démêler l'écheveau des échanges commerciaux, conflits, migrations et assistances entre le Canada et le Sri Lanka, illustrant le niveau surprenant des échanges entre les deux pays et explorant la signification et la qualité de ces connexions. L'assistance internationale au Sri Lanka est étroitement liée à l'ouverture des marchés aux investissements multinationaux qui commença en 1977. Cette libéralisation économique s'accompagne de périodes de conflit et de croissance macroéconomique au Sri Lanka. Cependant, la prospérité qu'on lui doit n'a pas profité d̀ toutes les classes sociales et à tous les groupes ethniques. En effet, les conflits au Sri Lanka ont été caractérisés par des révoltes de jeunes au chômage, des manifestations protestataires pacifiques et violentes de discrimination contre les Tamils du Sri Lanka et des représailles gouvernementales militaires dans les deux cas. Une longue période de croissance macroéconomique s'est terminée durant le dernier trimestre 2001, après le bombardement d'avions de ligne à l'aéroport international du Sri Lanka. La situation géopolitique et géoéconomique du Sri Lanka prit alors un virage abrupt. Dans ce contexte, l'Agence canadienne de développement international (ACDI) et d'autres organismes d'assistance aspirent d "remédier au conflit » et à favoriser l'établissement d'un Sri Lanka démocratique et pacifique par le biais de mesures d'édification de la paix et d'autres mesures d'assistance. Les conflits militarisés qui durent depuis au moins 20 ans ont produit des déplacements massifs de population à l'intérieur et à l'extérieur du pays, créant des migrants 
internationaux demandeurs d'asile. En 1999, le Sri Lanka fut pour le Canada le pays générant le plus grand nombre d'immigrants demandant le statut de réfugiés. Le Canada est le pays qui abrite la plus grande diaspora srilankaise au monde. En examinant la connexion entre la libéralisation économique et l'assistance, j'analyse ce qui la lie au conflit au Sri Lanka et à la migration au Canada.

'Sri Lanka peace deal forged on Canada's federal model' proclaims a 6 December headline on the front page of The Globe and Mail (Knox 2002). The article outlines the role of former Ontario Premier Bob Rae in briefing government and rebel negotiators on Canadian federalism during four days of peace talks in Oslo. Canada, among others, has long been a point of reference for constitutional model-builders in Sri Lanka. The rebel Tigers said they admired Canada's system because it includes mechanisms for self-determination, such as the 1995 Quebec referendum on sovereignty.

Conflict is increasingly globalised in terms of its antecedents, negotiations and outcomes. While conflict within the borders of a given country has largely replaced conflict between and among states as the prevailing framework of waging war, the migration implications of 'civil war' invariably seep beyond borders, generating an international context of response. The globalisation of the economy has also generated a significant degree of integration among nation-states. Migration tends, for example, to follow routes forged initially through bilateral economic and/or foreign policies (Sassen 1993).

An examination of transnational social, economic and political relations between Canada and Sri Lanka offers an opportunity to disentangle patterns of aid, trade and investment, conflict and migration both in a bilateral context and at a coarser global scale. For Sri Lanka, access to major funders of multilateral aid has been contingent on the opening of markets to multinational investment beginning in 1977. This turn toward economic liberalisation, scholars have argued, sowed the seeds of the current conflict (Gunasinghe 1984; Sivanandan 1990). There is considerable evidence that the fruits of these policies, based on steady macroeconomic growth in terms of gross domestic product (GDP), have not reached all segments of Sri Lanka's population. Decades of continuous economic expansion ended in July 2001 after 13 commercial airliners were destroyed in a rebel attack on Sri Lanka's international airport at Katunayake. While Sri Lanka's conflict is not a direct result of economic liberalisation, in my view, the economic damage and acute perceptions of instability after the 2001 airport attack do correspond to the recent impetus for peace. Such relationships point to the importance of political economy in understanding the war, and to the precariousness of a peace that might be negotiated in the context of economic crisis. Peace at any price is neither a viable nor a desirable option.

International assistance to Sri Lanka aims to correct for conflict and to promote a democratic and peaceful Sri Lanka where economic prosperity, in capitalist terms, may flourish. In terms of policy, Canadian aid contributes to a liberal democracy, with plans for accountable governance and sound economic policies in a well-managed, neoliberal economy. In 2000, Sri Lanka was the sixth largest country of immigration to Canada and its second largest source of refugees (CIC 2001). International migrations are embedded in larger social, economic and political processes, including foreign aid and investment policies and migration programs that shape the movement of people in nonrandom ways (Sassen 1996).

Extending this line of argument, immigration to Canada is best understood as a recursive and dynamic process that galvanises extant links with the countries from which newcomers emigrate. Immigrants do not simply abandon the social, economic and political connections of the place that they leave behind when they move to a new home (Basch, Glick Schiller and Szanton Blanc 1994; Mountz and Wright 1996; Faist 1999; Bailey et al. 2002). Many send remittances to family, friends and political causes, and some sponsor relatives 
to join them in their adopted country. Refugees, in particular, are likely to maintain different kinds of contact and linkages abroad after settling in Canada (Hyndman and Walton-Roberts 2000; Al-Ali, Black and Koser 2001). Burmese refugees in Vancouver, for example, hold ongoing fundraising activities to raise political awareness of human-rights violations in Burma and to assist other Burmese still struggling in Thai refugee camps. Conflicts that involve the abrogation of human rights and related forced migration, as in Burma and Sri Lanka, are not geographically contained within the borders of the countries in which they occur.

While 'civil war' in Sri Lanka technically occurs within the borders of the state, transnational ties generated by asylum-seekers and other migrants are part and parcel of the current conflict. The war in Sri Lanka is based on competing and territorially rooted Tamil and Sinhalese nationalisms, but the conflict is also perpetuated by those who are economically marginalised. These relations of conflict are by no means mutually exclusive. Unemployed men and women from southern Sri Lanka can enlist as soldiers and earn handsome salaries that enable them to support their families. Unemployment among both Tamil and Sinhalese youth has been a major factor contributing to the war (The Economist 2000). Economic liberalisation to attract foreign investment has not eliminated high unemployment rates, despite the introduction of free-trade zones and export-oriented activities. Remittances to the rebel Tigers, whether voluntary or extorted, also have the effect of protracting a war that might otherwise be short-lived (Wayland 2002). Those who flee their homes to seek safety or restore livelihoods may leave Sri Lanka to become part of this remitting diaspora. The conflict is not, then, a domestic matter. Asylum-seekers and other migrants from Sri Lanka seek new homes in Canada, India, Europe, the United States, Australia and elsewhere.

In what follows, current practices of Canadian aid disbursements in Sri Lanka are juxtaposed with current aid policy at Canada's International Development Agency (CIDA). Other exchanges between Canada and Sri Lanka, such as remittances and migrants, are also explored. The next section briefly traces the contours of contemporary conflict in Sri Lanka before moving on to examine external economies of influence and aid and their implications.

\section{Sri Lanka in Conflict}

Sri Lanka has experienced war since at least the 1983 pogroms, in which thousands of Tamils in Colombo, the Sri Lankan capital, were murdered and had their property looted and homes burned. ${ }^{1}$ The pogroms were retaliation for the killing of 13 highly ranking Sinhalese Sri Lankan soldiers by the Liberation Tigers of Tamil Eelam, or LTTE, on the Jaffna Peninsula (Swamy 1996). Almost 100,000 Tamils in Colombo were displaced, and many Tamil neighbourhoods were destroyed. 'There was hardly any Tamil family that escaped death, destruction or displacement' (Suryanarayan 2001, 1). Anti-Tamil violence left 90 percent of Tamilowned shops and businesses completely destroyed (Cheran 2000). The recent conflict between the LTTE and the government of Sri Lanka can be traced back to a series of violent confrontations beginning at this point (Spencer 1990; Jeganathan and Ismail 1995; Tiruchelvam 1996).

Well before the pogroms, the introduction of the 1956 Sinhala Only Act stirred up communal antagonism and generated considerable resentment among Sri Lankan Tamils (Gunasinghe 1987). This act declared Sinhala to be the only official language, removing Tamil as one of the statesanctioned languages. The political controversy generated by the act was exacerbated by a scheme in the 1970s to standardise examination marks for entrance to university so those writing exams in the Sinhala medium required fewer marks than those written in Tamil (Sivanandan 1990). Before 1956, Tamils were proportionately overrepresented in the civil service because of their high achievement of English-language proficiency. Until 1956, this was their passport to government employment. As Cheran $(2000,110)$ argues, 'The class dimension of the Sinhala Only Act must not be forgotten.... The battle of the languages was in reality a battle for government jobs.' Unemployment among the majority Sinhala youth generated considerable political pressure for the government to act in a manner that ironically consolidated identity based on nation, despite the economic antecedents of such identity formation.

\footnotetext{
1 In fact, a series of pogroms in 1977, 1979 and 1981 preceded those of 1983 (Cheran 2000, 113).
} 
The conflict in Sri Lanka has spawned large-scale displacement within the country and well beyond its borders, where a significant Tamil diaspora has emerged. There are more than 800,000 internally displaced persons in Sri Lanka, and the death toll now exceeds 60,000 (Refugee Council 2002). The brutality of the war is demonstrated by the fact that few or no combatants are captured alive and taken as prisoners of war (National Peace Council 2001). Some 40,000 families live in governmentrun 'welfare centres', and the remaining 140,000 families make temporary arrangements for refuge with family and friends (Perara 2001). Mass displacement, multiple displacements, long-term displacement and attacks on communities of displaced persons amid widespread militarisation across Sri Lanka present massive challenges to humanitarian and development organisationsboth national and international-that provide assistance to such groups. Estimates suggest that the vast majority of those displaced-78 percent-are of Tamil background, 13 percent are Muslim and 8 percent are Sinhalese (Suryanarayan 2001). Displacement has occurred more than once for many households, sometimes within the borders of Sri Lanka and sometimes beyond. The implications of such multiple displacements on one's livelihood and well-being cannot be easily documented, though the impetus to seek a safer, more stable life elsewhere becomes clear.

A ceasefire agreement (CFA) between the government and the LTTE was drawn up in February 2002 and was still holding at the time of writing. The CFA has meant that a number of military checkpoints have been dismantled and that major transportation routes to northern and eastern Sri Lanka have been reopened. In July and August 2002, for example, unprecedented numbers of pilgrims made their way to the Our Lady of Madhu Shrine in the northern province of Sri Lanka, near Vavuniya: 300,000 and 400,000 visited for the July and August festivals, respectively (Bishop Rayappu Joseph of Mannar, personal correspondence 26 November 2002). Nonetheless, no peace agreement or plan for the demobilisation of the warring factions has yet been reached. Preliminary peace talks between the LTTE and the Sri Lankan government were held in September, November and December 2002, with plans for future talks. On 24 November 2002, Sri Lanka's warring parties made their highest-level contact in 12 years in what was hailed 'a landmark meeting' to consolidate the bid to end Asia's longest-running ethnic conflict (Globe and Mail 2002a). Tamil rebels, however, rejected a U.S. appeal at the meeting to renounce violence (Globe and Mail 2002b).

Human rights continue to be violated by both sides, despite the ceasefire agreement. 'Despite repeated promises by the LTTE to end their use of child soldiers and to halt extortion of money and property from civilians in the north and east, these practices have continued. Human Rights Watch has received numerous reports of such incidents since February' (Human Rights Watch 2002; UTHR [J] 2002a). The CFA does not formally acknowledge human-rights issues faced by civilians. Human Rights Watch also points out the

urgent need to eliminate or reform the government's Prevention of Terrorism Act and to release the hundreds of detainees held by the Sri Lankan authorities without trial under its draconian provisions. Most of these detainees are Tamils arrested on suspicion of links to the LTTE. Many of them were arrested months or even years ago pending investigation, with no evidence to support police suspicions beyond their own confessions-often extracted under torture. (HRW 2002)

Similar observations have been made closer to the conflict and are worth quoting at length. The group University Teachers for Human Rights (Jaffna) (UTHR [J]) remarked that

We find that there is a lack of critical scrutiny of the ongoing peace process, particularly, among the civil society. The UNF [United National Front] government appears desperate to sustain the peace process as it sees the process as the only way to stabilise the economy outside the North and East....[W]e are increasingly being pushed into polarised positions, for the MoU [memorandum of understanding or ceasefire agreement] or against-without being able, critically and constructively, to engage with the ongoing peace process. What we have now is most NGOs avoiding reporting human rights violations in the Northeast by the LTTE. This they do in vain hope of not rocking the peace boat.... What is needed now more than ever is a genuine push to monitor and report all human rights violations whether by the LTTE or the Government. (UTHR [J] 2002a; emphasis added) 
During a two-week visit in June 2002, Derek Evans, head of a delegation for Amnesty International, was more optimistic: 'Human rights in Sri Lanka have improved as a result of the cease-fire but the situation will remain vulnerable until the government and the LTTE take steps to guarantee a human rights framework for the peace process' (Amnesty International 2002). Taken together, the unprecedented high-level meeting between the Sri Lankan prime minister and the negotiating leader of the LTTE and the warnings of human-rights groups provide mixed signals for the prospect of peace.

The current ceasefire opens up a precarious space for optimism, one that is highly circumscribed by ongoing human-rights violations and concerns that peace should not be negotiated at any price. As in so many other conflict zones (Rwanda, Sierra Leone, East Timor, BosniaHerzegovina), civilians have been the target of real or potential violence. ${ }^{2}$ Civilians are the main casualties of Sri Lanka's war, if not in terms of the death toll, then most certainly in terms of the dispossession toll. Although Sri Lanka's war is characterised as one of 'ethno-nationalist conflict', the idea that it is based on tensions internal to the country tells only part of the story. I aim to extend this argument by illustrating how transnational processes shape political and economic conditions in Sri Lanka by elucidating the ways in which (1) international lenders, investors and donors influence Sri Lanka's economic policy, (2) conflict spawns migration beyond the country's borders and (3) Sri Lankans abroad remit to their families and contribute to this conflict at home. ${ }^{3}$

2 As Boutwell and Klare (2000) have argued, 60 to 80 percent of casualties in contemporary warfare are civilians, and Sri Lanka is no exception.

3 It is important to point out that many Sri Lankan Tamils abroad do not support the LTTE, and that their contributions are sometimes made unwillingly.

The sophistication of the LTTE's financial apparatus is also demonstrated through an extensive tracking system. The LTTE in Sri Lanka keeps records of people living and working abroad, their earnings, and-through connections in local banks-the amount of money they send back to their families in Sri Lanka. When money is sent to a particular household, a LTTE representative in Sri Lanka visits the household and asks for a portion of the funds.... Fear of the Tigers is clearly evident within portions of the Tamil community (CSIS n.d., 6).

\section{Nonaligned to Realigned: Sri Lanka's Integration into the Global Economy}

Foreign assistance and development aid during the Cold War were as much about forging geopolitical allies and proving the superiority of capitalist economies as they were about remedying the 'underdevelopment' of nonaligned Third World nations. W. W. Rostow (1960), a major proponent of capitalist industrialisation as the superior means to 'develop' a country, even called his treatise The Stages of Economic Growth: A NonCommunist Manifesto. Eurocentric data, tautological reasoning and Cold War posturing aside, Rostow's theory of modernisation is interesting because of its focus on the nation-state as an independent object of development (McMichael 1996). Dependency theorists in Latin America were quick to criticise Rostow's theory for a variety of reasons, principally because it failed to take into account power relations between the First and Third worlds, including unequal trade relationships and terms of exchange that emerged from the colonial period (Cardoso and Faletto 1979; Mittelman 1988). The appropriate response, argued dependency theorists, was not to copy the export-oriented capitalist model of the 15 European countries analysed in Rostow's study, but to substitute locally made goods for imported ones as a step towards self-sufficiency.

While criticisms can also be made of dependency theory, these theorists forced Rostow and his allies to look beyond the borders of impoverished nation-states for an explanation that included external economies of trade and finance. Virtually no country has been able to escape the influence of the economic liberalisation measures that were to follow, as many Third World countries became increasingly indebted to First world banks in their efforts to modernise. These contrasting conceptions of where the problem of underdevelopment lies (that is, within Third World states versus between First and Third world states) may appear tangential to the analysis put forth, but they point to parallel arguments about the scale of analysis that are explored later in the paper.

From the colonial experience, Sri Lanka (or Ceylon, as the country was called until 1972) inherited an export economy in tea, rubber and coconuts that was prosperous but dependent on international market conditions and terms of 
trade (Stokke 1998). State socialism and importsubstitution strategies characterised the Sri Lankan economy immediately after independence from Britain in 1948, a period in which political power was rooted more in contested class formation and relations than in national identity or ethnicity (Jayawardena 1990). Members of the Sinhalese political elite, through a series of patron-client relations, made general concessions to the Sinhalese rural middle and lower classes in order to be returned to power (Stokke 1998). From the 1950s to the electoral victory of the United National Party (UNP) in 1977, the government appropriated significant sums from the economy and redistributed some of the surplus through various economic and social development programs (Gunasinghe 1984).

Postcolonial import-substitution industries created economic growth for a time in the early 1960 s, but this growth was soon constrained by a saturated domestic market and a lack of competitiveness in the export market (Stokke 1998). '[T]he system of quotas, permits and licenses, a product of the policy of import substitution, made state patronage essential for any individual or commercial venture in the private sector' (Gunasinghe $1984,199)$. From the late 1950 onward, the economy was hamstrung by the inability to finance an adequate level of imports (Moore 1990). The cost of import-substitution policies was high, and included extremely high unemployment rates among educated middle-class and lower-middleclass youth (Athukorala and Jayasuriya 1994). The early 1970s was characterised by 'a deepening accumulation crisis of democratic socialism and equally severe legitimation crises for Tamil and Sinhalese class alliances and political networks' (Stokke 1998, 101). These crises were manifested in a series of local confrontations that were part of the coordinated insurgency of the Janatha Vimukthi Peramuna (JVP, or People's Liberation Front) in April 1971. The insurgents were comprised largely of unemployed and underemployed youth from the rural petty bourgeoisie and middle peasantry (Stokke 1998, 101).

In the mid-1970s, the Sri Lankan government unsuccessfully requested loans from the International Monetary Fund (IMF). This changed with the election of the UNP government in 1977, at which time Sri Lanka opened its markets to unbridled capitalist development and export-oriented indus- trialisation; at the same time, it promised to create a just and free society that included Tamilspeaking people. ${ }^{4}$ Within two weeks of taking office, however, police burnt down the market in Jaffna, sparking a reign of terror and violence against Tamils throughout the country (Sivanandan 1990, 236). The newly elected prime minister, J. R. Jayewardene, did little to quell the violence. At the same time, the state abandoned its regulatory role as provider to the poor, handing over control of the economy to the private sector (Gunasinghe 1984; Cheran 2000). Economic liberalisation meant an end to many of the concessions that held ethnic and class alliances together (Stokke 1998). Newton Gunasinghe (1984) takes this argument a step further and argues that there is a direct link between economic liberalisation and the anti-Tamil violence between 1977-1983, and that this violence triggered the civil war between the Sinhalesedominated state and militant Tamil separatists. While capitalism began to flourish, Tamil areas remained largely excluded from investment (Sivanandan 1990, 241).

With the opening of Sri Lanka's economy to foreign investment in 1977, the IMF and the World Bank did come to Jayawardene's financial aid with major loans, in exchange for devaluation of the rupee and cuts to welfare programs. Western aid experts followed with plans for the establishment of a free-trade zone, a large hydroelectric dam project and an international tourism industry. A major prerequisite for all of these investments was political stability. This was assured in September 1978 by a new constitution that was pushed through parliament in three weeks, strengthening executive power in the office of the president. 'And if investors needed further reassurance, Article 157 stipulated that no future government could revoke or alter any treaty or agreement entered into-on the basis of a two-thirds majority in parliamentwith a foreign state or "its nationals ... corporation, companies and other associations" for the "promotion and protection of their investments"' (Sivanandan 1990,238$).{ }^{5}$ Once foreign investment arrived in Sri Lanka, it was carefully protected by

4 Sri Lanka was the first in South Asia to liberalize its economy in 1977 (The Economist 2000).

5 Gunasinghe $(1987,66)$ argues that $[E]$ thnic consciousness acquired pronounced expression and the major ethnic communities in Sri Lanka drifted apart from one another through the competitive economic and political processes'. 
the state. The security and predictability of investment, if not political stability per se, were key requirements for foreign involvement in the Sri Lanka economy. In return, foreign aid flowed freely. 'In the early 1980s Sri Lanka became, on a per capita basis, one of the most heavily aided nations in the world' (Moore 1990, 354). ${ }^{6}$

Economic liberalisation did not signal 'any hard choice between liberalising the economy or meeting demands for political patronage. For the rapid and massive inflow of foreign aid and the consequent expansion of the absolute and relative size of the public sector... provided abundant patronage resources' (Moore 1990, 352). Sri Lanka had become a favourable partner in the eyes of bilateral and multilateral aid and finance institutions due to its commitment to economic deregulation and free-market policies and its relatively democratic status in terms of human rights and welfare:

Here indeed was a deal waiting to be made. But it was implicitly a package deal, and one which had visibly to be in place rather quickly. Continued support from the World Bank and IMF would implicitly be contingent on enthusiasm for Sri Lanka in international business circles and in the foreign and trade ministries of the industrialized countries. But foreign capital would look at Sri Lanka again only if the new government could reverse the country's reputation for political radicalism and electoral instability. Hence a whole series of urgent policy measures to create a new business image. (Moore 1990, 354-355)

Distinct from Gunasinghe's argument, Mick Moore refutes any causal link between economic liberalisation and violence, but contends that the large net increase of foreign aid that accompanied open markets, along with a larger and more salient public sector in Sri Lanka, may well have encouraged and sustained authoritarian practices. Stokke (1998) notes that during the 1970s, groups of marginally employed urban dwellers were financed by these new public investments as part of an institutionalised 'thuggery' throughout the country. Those holding the purse-strings could control rebellious elements at arms length

6 In 1985, gross aid disbursements comprised 56 percent of government capital expenditures and 19 percent of total government expenditures (Moore 1990). by hiring from this cohort whose tactics were punitive.

Despite the ongoing conflict in Sri Lanka since 1983, macroeconomic growth has been steady over the past two or more decades (Sriskandarajah 2002). In documenting the basic contours of economic growth, foreign direct investment (FDI) and official development assistance (ODA), the impact of these changes becomes evident. Per capita gross domestic product (GDP) shows steady gains since 1975 , as noted in Table 1. While these are impressive gains on paper for investors in Sri Lanka and their government counterparts who received loans and aid in return, however, they do not measure the distribution of this newfound wealth, if any, among different segments of the population. Table 2 illustrates the increase in private capital flows, especially foreign direct investment (FDI), in relation to much larger flows of official development assistance, drawing from a collation of data by Dhananjayan Sriskandarajah (2002).

While FDI increased four-fold over eight years, levels of ODA dropped off significantly during this same period. The platform of President Chandrika Kumaratunga's party in 1994 was based on the forging of a peace agreement with LTTE. The LTTE withdrew from the talks, however, soon after Kumaratunga's People's Alliance was elected. Official development assistance appears to have dropped off as the war intensified and the government sought a military solution to the conflict.

The Sri Lankan economy grew at an average of 4.7 percent between 1980 and 1999 (The Economist 2000 ), despite the conflict that prevailed through much of the period. In 2000, per capita GDP had the highest value in terms of purchasing power parity over the previous 25 years, at US $\$ 3,530$ (UNDP 2002). That same year, the economy grew

Table 1

CDP per capita in 1995 US\$, selected years, Sri Lanka

\begin{tabular}{lc}
\hline Year & GDP/Capita \\
\hline 1975 & 382 \\
1980 & 452 \\
1985 & 536 \\
1990 & 590 \\
1995 & 700 \\
1999 & 802 \\
\hline
\end{tabular}

SOURCE: UNDP (2001); Sriskandarajah (2002). 
Table 2

Sri Lankan foreign direct investment (FDI), official development assistance (ODA) and debt indicators, 1990 and 1998

\begin{tabular}{lccccc}
\hline Year & $\begin{array}{c}\text { FDI in } \\
\text { US\$ Millions }\end{array}$ & $\begin{array}{c}\text { ODA Total in } \\
\text { US\$ Millions }\end{array}$ & $\begin{array}{c}\text { ODA as US\$ } \\
\text { per Capita }\end{array}$ & $\begin{array}{c}\text { ODA as \% of GNP } \\
\begin{array}{c}\text { External Debt Total in } \\
\text { US\$ Millions }\end{array}\end{array} \quad \begin{array}{c}\text { External Debt as } \\
\% \text { of GNP }\end{array}$ \\
\hline 1990 & 43 & 780 & 43 & 9.3 & 5,863 \\
1998 & 193 & 490 & 26 & 3.2 & 8,526 \\
\hline
\end{tabular}

SOURCE: Sriskandarajah (2002).

at a rate of 6 percent (Government of Sri Lanka 2002). In 2001, this fell to -1.4 percent-a precipitous decline coincident with the heightened consciousness of political instability after July 2001.

Remittances to Sri Lanka constitute another dimension of economic integration beyond its borders. While the aggregate data shown in Table 3 cannot be broken down into remittances between Canada and Sri Lanka specifically, the growth of remittances generally is worth noting. In recent years, private remittances to Sri Lanka have exceeded FDI to the country by three to four times; they have exceeded foreign assistance contributions by two to three times, and comprised about 15-20 percent of export earnings, or 5 percent of gross national product (GNP) (Sriskandarajah $2002,10)$. Both labour migration and forced migration based on asylum contribute to remittance revenues. To some extent, labour migration, too, is predicated on the conflict, which has left many displaced Sri Lankans with no local livelihood, spawning the migration of household members abroad (Brun 2002).

Sri Lanka's shift from a nonaligned socialist state based on a postcolonial export economy to a more

Table 3

Total private remittances, selected years, for Sri Lanka

\begin{tabular}{lr}
\hline Year & US\$ Millions \\
\hline 1975 & 9 \\
1980 & 152 \\
1985 & 292 \\
1990 & 401 \\
1995 & 790 \\
1999 & 1,050 \\
\hline
\end{tabular}

SOURCE: Sriskandarajah (2002). neoliberal state characterised by export-oriented industrialisation has met with mixed results. On the one hand, macroeconomic growth has been relatively steady since 1977, when trade liberalisation was introduced. Political stability and the material prosperity of all Sri Lankans, however, have been elusive. The LTTE and the government of Sri Lanka have been at war throughout most of this period. Ironically, remittances contribute a growing portion of the country's export earnings and help many households secure income that they can no longer access within the country. Yet many of the migrants who send funds to Sri Lanka were themselves refugees and are now living abroad as immigrants or citizens of other countries. The war did not appear to have interfered with macroeconomic growth in Sri Lanka until 2001 , with negative growth in the final quarter.

While the airport bombing and the events of September 11, 2001 have contributed, in my view, to this economic crisis, my purpose here is not to explain why the economy sank so quickly, but to note the coincidence of these events with the current CFA and peace talks. I now move to Canada to examine the relation of the Sri Lankan Tamil diaspora to its country of origin. Having commented on remittances in general, I articulate more fully the shape and scope of the diaspora and connections between the two countries.

\section{The Tamil Diaspora in Canada}

Sri Lankan Tamils have been called the 'asylum diaspora', reflecting the claims that they have made in order to stay in the countries in which they have sought protection (McDowell 1996). Like other diasporas, Sri Lankan Tamils are scattered and dispersed across the globe, with concen- 
trations in Canada, India, Europe, Australia and the United States. Estimates of the Tamil diaspora in Canada range from between 110,000 and 200,000 (Wayland forthcoming) to 400,000 (Sriskandarajah 2002). To a population of fewer than 2,000 Tamils in Canada in 1983 (Aruliah 1994), more than 25,000 were added between 1984 and 1992; in the 1991 census, Tamils were the fastest-growing ethnic group in Metro Toronto (Cheran 2000). Canada's Tamil population is thought to constitute the largest Sri Lankan diaspora in the world (Wayland forthcoming), and Toronto is the city with the largest number of [Sri Lankan] Tamils in the world' (Cheran 2000, 170). ${ }^{7}$ This diaspora, significant in terms of both size and concentration, maintains strong ties with Sri Lanka.

Aihwa Ong (1999) speaks of 'flexible citizenship' in reference to the condition of interconnectedness and mobility that people experience across space in an increasingly integrated world. Such citizenship, she explains, 'refers to the cultural logics of capitalism, travel and displacement that induce subjects to respond fluidly and opportunistically to changing political-economic conditions' (Ong 1999, 6). Much has been made of transnational ties-referring to the continuous social, political and economic fields that traverse international borders-that the LTTE maintains with members of the Tamil diaspora. In a Canadian context, some media analyses reflect reactionary or anti-immigrant positions, based on an undifferentiated and highly problematic assumption that all Tamils in Canada are Tiger supporters: ${ }^{8}$

The Tigers aren't the only international terrorist group that raises money in Canada, but they have certainly been one of the most effective, generating by one estimate more than $\$ 22$ million last year to finance a wave of ethnic warfare in northeastern Sri Lanka that has left 60,000 dead....

7 Cheran (2000) points out that recent population estimates for the district of Jaffna are 200,000 , implying that the city Jaffna hosts fewer people than the district. The entire Jaffna peninsula is thought to have approximately 550,000 persons, considerably fewer than it hosted before the conflict in 1983.

8 It should be noted that not all immigrants to Canada from Sri Lanka are of Tamil background. Sinhalese and Muslim Sri Lankans have also settled in Canada.

9 Rohan Gunaratna is a research associate at the Centre for Study of Terrorism and Political Violence at the University of St. Andrew's in Edinburgh (Sengupta 2000).
While it is impossible to know exactly how much money is raised in Canada to support the LTTE, Dr. Gunaratna ${ }^{9}$ estimates that more than $\$ 12$ million in donations were collected last year, as well as $\$ 10$ million in business revenues. (Bell 2000)

Multiple news media and intelligence sources, however, chronicle these economic and political connections.

The CSIS [Canadian Security Intelligence Service] report... says that between $[\mathrm{Cdn}] \$ 1-\$ 2$ million is raised here each year for the Sri Lankan guerrilla group, making Canada one of the largest contributors worldwide, and alleges that some of the money is being channeled to the LTTE's weaponsprocurement arm in Thailand. (Munasinghege 2000)

So oceans away from the mass graves and suicide bombers that have become hallmarks of the civil war, the Tamils of Toronto hold pledge drives on Tamil radio, fill tills on shop counters and solicit money door-to-door in Tamil neighborhoods. Experts estimate they send anywhere from $\$ 7$ million to $\$ 22$ million a year [from Canada] in direct and indirect support for the guerrillas. (Sengupta 2000)

'As far as a list of countries is concerned, Canada is the worst culprit with regard to funding,' said Canada's High Commissioner in 1995 (Morris 1995; Wayland forthcoming, 21). 'Certain months of the year are known to be fundraising months when Tamils can expect someone from the community-often a former Tiger militant-to come by and collect money for the cause. Some Tamils welcome this visit, while others refer to it as extortion' (Wayland forthcoming, 21). Canadian weekly Maclean's claimed that Tamils targeted for donation were asked to pay 6 percent of their gross income to the Tigers (Kaitha 1996; see also Wayland forthcoming). Tamil leaders in Canada have argued that these estimates are overstated, and that most money remitted goes back to family members and relief organisations (Morris 1995; Wayland 2002).

Following the events and in the aftermath of September 112001 (9/11), the LTTE's links to Canada have made more headlines and captured more attention. Canada designated the LTTE as a terrorist organisation under federal financing regulations on 7 November 2001 (Bell 2001). Political scientist 
Sarah Wayland (forthcoming) has analysed the relation of the Tamil diaspora to the conflict. Wayland (forthcoming, 4) argues that a transnational opportunity structure connects Sri Lankan Tamils in the Canadian diaspora with those in Sri Lanka: '[T] he formation of identity networks in the Tamil diaspora has enabled the Liberation Tigers of Tamil Eelam (LTTE) or Tigers to engage in protracted insurgency against the Sri Lankan government army'. Wayland (forthcoming, 16) links ongoing identity formation to information exchange within the Tamil community via Tamillanguage newspapers, radio, the Internet and ethnic organisations, awareness-raising of the Tamil struggle through marches, conferences and the lobbying of government officials, and lawful, as well as unlawful, fundraising. She notes that all of these activities reinforce an independent Tamil identity-and, I would add, a Tamil nationalism the imagined homeland of which is Tamil Eelam. Cheran $(2000,210)$ has eloquently argued, however, that this Tamil nationalism has 'failed to evolve into an inclusive national liberation project'.

Nevertheless, the scope and organisational capacity of the Sri Lankan Tamil diaspora in Toronto is remarkable. A bilingual Tamil community directory of businesses and services for this community, thamilar mathiyil (Amidst Tamils), has been published since 1990 and has grown to several hundred pages in length. There are ten weekly Tamil language newspapers, four Tamil language radio stations and three cinemas that show Tamil language films (most are produced in Tamil Nadu). Toronto is also home to the largest Tamil video and music store in the world (Cheran 2000). "The major community organizations, the Tamil Eelam Society of Canada and the World Tamil Movement (WTM), are pro-LTTE organizations' (Cheran 2000, 181). The Tamil Eelam Society is the also largest ethnospecific provider of social services to Tamils in the province of Ontario (Wayland forthcoming). These organisations and businesses point to transnational ties between Canada and Sri Lanka, but are more indicative of the sizeable presence of Sri Lankan Tamils who left their country during the conflict and of the politics they bring to these organisations.

Turning to Canadian aid to-and trade with-Sri Lanka, this analysis of the conflict recognises links among international governments, nongovernmental organisations (NGOs), the Sri Lankan government, the LTTE and Sri Lankans living overseas. ${ }^{10}$ As Mark Duffield has noted, protracted conflict is an expression of local and global processes (cited in Goodhand and Hulme 1999, 19). Without a strong understanding of 'new political formations emerging on the global periphery,' humanitarian aid will be incorporated into the fabric of political violence (Duffield 1996, 173). International funding of either party to the Sri Lankan conflict has obvious political implications for the nature of the conflict, but even humanitarian and development assistance provided by donors to NGOs that declare neutrality may have political consequences.

\section{The CIDA: Promoting Peace and Stability through Good Governance}

Long before foreign direct investment and remittances became significant to the Sri Lankan economy and to the LTTE, Canada was loosely associated with Sri Lanka through its membership in the British Empire and Commonwealth. Through these connections, the first Sri Lankan immigrants came to Canada beginning in 1951, via Britain. They brought with them impeccable educational credentials and middle-class standing (Vaitheespara 1999). These immigrants were at once a legacy of the common colonial regime and subject to the largely exclusionary measures of a white settler society in Canada. ${ }^{11}$ Canada's connections to Sri Lanka were galvanised in January 1950 at the

10 Trade between Canada and Sri Lanka is modest but increasing, especially for Canadian imports of Sri Lankan goods. Canada was Sri Lanka's thirteenth largest destination country in terms of exports in 1997, but this represents only 1.2 percent of Sri Lankan exports. Canadian exports to Sri Lanka represent less than 2.5 percent of Sri Lanka's total imports (Department of Census and Statistics, Sri Lanka 2001). When the provisions of the Multi-Fibre Arrangement terminate in 2005, as ordered by the World Trade Organization, Sri Lanka's stature within the garment sector will be tested. Until now, 'quota hoppers' in the East and South Asian markets have taken advantage of the unused quotas in Sri Lanka to produce apparel at competitive prices (Moore 1990). Nonetheless, it produces a wide range of apparel on continuous contracts for brand names such as the Gap, Liz Claiborne, Tommy Hilfiger, Abercrombie and Fitch, Ralph Lauren and others. Sri Lanka's three export-processing zones and relatively inexpensive labour make it an appealing location for foreign direct investment (FDI).

11 South Asians who tried to land on Canada's West Coast 50 years earlier, were largely excluded by regulations that prevented them from doing so (Mongia 1999). 
Commonwealth Conference on Foreign Affairs, held in Colombo (Colombo Plan 2001). The meeting's deliberations included a pledge to draw up development programs that would provide a framework for international cooperation among Commonwealth countries. This intergovernmental initiative became known as the Colombo Plan, a plan that continues to shape the economic and social development in the Asia-Pacific region today. $^{12}$

Canada's International Development Agency (CIDA) has delivered assistance to developing countries such as Sri Lanka over the past three decades. Canada's development aid to Sri Lanka is based, in part, on a tradition of assisting those within the Commonwealth (Zukowsky 2001). Despite the agency's recent announcement of a new policy espousing, among other things, greater geographic concentration of Canadian aid in fewer countries (CIDA 2002), Canada is unlikely to cut off bilateral aid to Sri Lanka given these longstanding ties (interviews A and B). At roughly Cdn $\$ 5.5$ million per year, the CIDA's bilateral contributions to Sri Lanka are relatively modest (George 2001). This bilateral commitment is not significant enough to put Canada on the 'top ten' list of donors of net official development assistance, which is topped by Japan (US $\$ 167$ million) and followed by the Asian Development Bank (US\$94 million) and the World Bank (US\$59 million) (Sriskandarajah 2002). ${ }^{13}$ Additional multilateral funds and monies provided by the office of the Canadian High Commissioner in Sri Lanka to NGOs such as CARE and Médecins Sans Frontières (MSF Holland) push total

12 I thank Terry McGee for pointing out this link, as well as the parallel connections that were formed through Canada's membership in the Francophone association of countries.

13 These statistics require more analysis. Does the end of the Cold War, of which development assistance was a key political component, mean that development aid is outdated, redundant, politically less attractive, especially in a country destabilised by war? Between 1992 and 1998, total assistance from the countries comprising the Organization for Economic Cooperation and Development (OECD) declined from US $\$ 60.8$ billion to US $\$ 51.5$ billion, and aid as a percentage of GNP in these countries fell from 0.33 percent to 0.23 percent (Thérien and Lloyd 2000). There is evidence to suggest that development aid is declining, while 'soft money' for voluntary contributions to humanitarian crises is increasing. Aid transfers that enhance stability in recipient countries by increasing economic growth and preventing possible out-migration are already in place (Macrae and Leader 2000; Duffied 2001).
Canadian contributions in Sri Lanka up to approximately Cdn $\$ 10$ million (interview $\mathrm{C}$ ).

The manner in which Canada's bilateral assistance is delivered is unusual: 'In light of the present conflict, since 1991, Canada's assistance to Sri Lanka is channelled exclusively through NGOs and institutions that can address the political, social and economic causes of the conflict' (CIDA n.d.; interview C). While this is categorised as a 'bilateral' assistance package, Canada is the only donor in Sri Lanka that does not fund government ministries or programs directly. Nonetheless, the CIDA is the fourth largest contributor to programs based in the conflict-ridden parts of northern and eastern Sri Lanka. ${ }^{14}$ Canada is also the only donor in Sri Lanka with a peace-building fund, established to promote human rights and democratic values in this war-torn country (interview $\mathrm{C}$ ). Based on the abysmal human-rights records of both parties to the conflict in recent years, the CIDA continues to avoid funding government budgets (interview $\mathrm{C}$ and $\mathrm{F}$ ).

Doing development in a war zone is a difficult undertaking at best, given the risk that aid may be diverted to fuel the conflict, either directly or indirectly. 'Development success can be a peacebuilding failure' (interview G). CIDA has avoided funding capital-intensive projects-the conventional 'bricks and mortar' approach-opting instead for 'knowledge-based' training and projects to enhance institutional and communitybased capacity-building (George 2001; de Alwis and Hyndman 2002; CIDA 2002). ${ }^{15}$ Community-

14 The war has generated 'border areas' and 'lines' demarcating territories controlled either by the LTTE or the Sri Lanka Army. Some of these spaces overlap: a road may be controlled by the Sri Lankan Army by day and the LTTE by night-for example, in the Nilaveli part of Trincomalee District. We collected reports of women who were raped on one side of the 'line' by perpetrators who then returned to the other side to escape detection and conviction for their crimes. There are literally two economies of accountability and justice at work, sometimes within a given town.

15 Many CIDA dollars are allocated to World University Services of Canada (WUSC) in Sri Lanka, an NGO that has in place a longterm social and economic strategy to upgrade skills among those living in war-affected areas. Between 1998 and 2000, the CIDA funded WUSC to retrain 2,461 persons, the majority of whom are Tamil and Muslim (CIDA n.d.). It is important to note that people living in Tamil-dominated areas such as the Wanni, Trincomalee and Batticaloa areas are not allowed to leave their home areas without government permission, and even then only for short periods and good reason. Thus, this training provides a constructive local activity to those otherwise dispossessed by the war. 
based training initiatives avoid diversion of funds by paying for vocational programs and enhancing 'human capital' in a politically unstable climate. Due to the constraints imposed by conflict, peace-building activities among civil society groups also constitute a major budget item (interviews $D$ and $E$ ). The CIDA's stated aims are to promote economic reforms, human rights and democratic values in Sri Lanka by promoting peace initiatives among Muslims, Sinhalese and Tamils in the country (CIDA n.d.).

While improving access to or quality of education may seem like a nonmilitarised and safe investment, however, such aid is at risk of being deployed for other means. Parents in LTTEcontrolled areas of Sri Lanka have avoided sending their children to school because it is considered a training and recruitment ground for the Tiger rebel group (UTHR [J] 1999 10). Entire classes of students have disappeared to serve as LTTE cadres under the leadership of their teachers. Similar projects in the government-controlled areas can also prove problematic. The government is in a position to pour more money into the defence industry and to fortify its military position in the current conflict if it knows that aid disbursements of funds for education, health and social services will be provided by international donors. These scenarios illustrate the potentially negative political impact of donor aid, but they certainly do not justify its withdrawal. The terms attached to aid, however, are an important consideration for all parties concerned.

\section{The new CIDA}

In the context of Sri Lanka, Moore $(1990,341)$ pointedly asks, "Is there a positive symbiosis between the liberal economy and the liberal polity?' Put another way, is there a correlation between capitalist economies and democratic state? Generally speaking, he says, historical evidence provides a positive answer. Moore notes, however, that economic liberalisation as a conscious and urgent attempt by the state to bring about particular changes in the economy is distinct from a noninterventionist path of economic development. The political correlates of economic liberalisation are more ambiguous. Nonetheless, the peaceful liberal polity has become both the prerequisite to and the promise of foreign aid in post-Cold War and post-9/11 contexts.
Development agencies are beginning to reinvent themselves and their policies in relation to countries affected by political instability. Those that are considered 'unstable' may be reformed through appropriate changes to economic policy and governance processes (CIDA 2001, 2002). As promoted by the World Bank (1998), development aid is becoming increasingly conditional upon political stability and open markets. If peace is considered a precondition for prosperity (Sivanandan 1990), then development aid may be an incentive for recipient countries affected by conflict to cooperate with donor agencies (Macrae and Leader 2000). Such conditionality on aid may impute a colonialism of compassion in which donors dictate the terms of assistance (Hyndman 2000). Questions of whose peace and on whose terms are pressing ones in the context of aid programming that aims to integrate trade and foreign policies more closely with development assistance under the guise of 'international cooperation'. In highlighting the link between aid and peace, development objectives become increasingly tied to security agendas (Duffield 2001).

In Sri Lanka, any peace agreement that allows markets to flourish while spaces of dissent for Tamil civilians rapidly shrink under increasing LTTE control is unlikely to usher in peace. As the UTHR (J) (2002b) recently noted, '[T]he right to organize politically, to speak out, to elect representatives and for schools and offices to function normally are invaluable assets to a healthy peace process... Nothing tangible has been done to enhance the dignity and security of Tamils and in the event of war it will be back to square one'. One academic and activist I interviewed maintains that peace initiatives funded by foreign donors and implemented by Sri Lankan NGOs would do little to change current arrangements: 'The question is how to challenge the status quo... from outside the liberal economy of power' (interview $\mathrm{H}$ ). Understanding the impact of 'NGOisation' (Lang 1997) or the building of civil-society institutions financed by foreign donors represents an important area for further research, particularly in long-term conflict settings such as Sri Lanka. Another informant illustrates a similar point in relation to the CIDA's programming, arguing that Ahimsa, a CIDAsponsored peace group named after one of Gandhi's political concepts, distorts the concept's history and meaning. In Gandhi's day, when there was a 
British colonial monopoly on salt, Gandhi organised a march to the sea to make salt. In so doing, he acted outside the legal structures of government. His act of civil disobedience challenged the legitimacy of the law itself by contesting accepted rules and norms of organised politics (interview I). That foreign donors are wary of supporting things that are outside the legal structures of government is understandable and no doubt appreciated by the government in power. Their strong, liberalising presence in the country, however, has significantly transformed how civil-society dissent-excluding political parties and trade unions-is now imagined and practiced (interview $\mathrm{H}$ ). The limits of a liberal peace become apparent.

The CIDA has embarked on its path of reforming development assistance with the recent release of 'Canada Making a Difference in the World: A Policy on Strengthening Aid Effectiveness' (CIDA 2002). The policy aims to reward low-income developing countries that demonstrate 'sound' (i.e., competitive, open-market) economic policies and 'good governance' (i.e., stability and low levels of corruption). Similar policies have been implemented in the United Kingdom, the Netherlands and the U.S. (Macrae and Leader 2000). This new direction brings together development agencies, foreign policy and international trade departments and financial institutions in a number of donor countries and across several government departments in each country to coordinate development programming, enhance investment potential and promote security in 'nonstrategic' developing countries. As such, it points to the integration of development aid with trade and security policies.

This approach also promotes a shift from bilateral project-based programs of development activities to more multilateral macroeconomic sectoral approaches based on partnerships with governments. '[T]he realities of globalization and growing international interdependence are lending increased weight to a rationale for aid based as well on "enlightened self-interest" or mutual benefits. The emphasis here is on long-term interests, which are shared by all countries, rather than on narrow national interests' (CIDA 2001). 'International cooperation' appears as the catchword for a unified and multilateral approach to providing development aid. What is interesting about Canada's position, among those of other donors, is the conditionality of aid. Open markets and good governance become prerequisites for full bilateral aid. In the case of Sri Lanka, this policy has yet to be put to the test (interview C). An improved human-rights record on the part of both the government of Sri Lanka and the LTTE would be part of any governance audit and a prerequisite for full bilateral relations between the two countries. Canada's policy to 'strengthen aid effectiveness' is reminiscent of economic liberalisation measures of the 1970s in Sri Lanka, when loans and development aid were predicated on open markets and neoliberal economic policies.

One goal of the CIDA's new policy, in general terms, is to mitigate migration from developing countries by enhancing economic development and political stability in them.

Interdependence means that there is a convergence of interests among states around a wide array of issues-the environment, peace and security, health and the suppression of disease, economic and financial stability, migration and transnational crime. All states have interests in these issues-which can also have a strong values base-and advancing these interests requires, to a growing extent, improved international cooperation...

... Canada's border is long and open to both commerce and people. Since disease does not need a visa, we cannot be healthy in an unhealthy world. (CIDA 2001, 4, 7; emphasis added)

This new direction in development policy at the CIDA has an important security dimension. A clear set of geopolitical concerns is articulated in relation to development aid and policy. This excerpt also points to a retrograde geopolitical discourse in which individual Third World nationstates are the source of disease migration, and transnational crime. As with Rostow's analysis of deficient development, the problem to be solved by aid agencies lies within such nations, not in their external trade relations with or degree of economic integration into First World countries. Given the external economic relations that Sri Lanka and other developing countries maintain with investors, migrants, donors and traders, this framing of the problem as lying within a country's borders involves a particular invocation of scale that is untenable. Despite the documented networks of aid, trade, investment and remittance, 
Table 4

Immigration to Canada by top ten source countries, 1991-2001

\begin{tabular}{lcr}
\hline Country & \% of Immigrants & Rank \\
\hline China, People's Republic & & \\
India & $10.8 \%$ & 1 \\
The Philippines & $8.5 \%$ & 2 \\
Hong Kong & $6.7 \%$ & 3 \\
Sri Lanka & $6.5 \%$ & 4 \\
Pakistan & $3.4 \%$ & 5 \\
Taiwan & $3.2 \%$ & 6 \\
The United States & $2.9 \%$ & 7 \\
Iran & $2.8 \%$ & 8 \\
Poland & $2.6 \%$ & 9 \\
\end{tabular}

axcept Hong Kong.

SOURCE: Clobe and Mail, 2003

the CIDA's policy highlights a desire to maintain a clear boundary between 'us' and 'them'. Yet Sri Lanka continues to be a major source of immigration to Canada.

\section{Migration to Canada}

Transnational connections between Sri Lanka and Canada are an expression of conflict and displacement in Sri Lanka and constitute a continuous sociospatial field between the two countries. Conflict and war are not simply 'domestic' problems when they produce refugees and/or refugee claimants, many of whom seek new homes in Canada.
This section traces migration patterns between the two countries, noting that Sri Lanka is a significant 'sending' county to Canada in terms of migration and outlining reasons for these links.

Sri Lanka is a relatively small country of 18.8 million people, more geographically distant from Canada than Europe. Yet in the year 2000, Sri Lanka was the sixth largest source country of immigrants to Canada, sending 5,841 people, or 2.57 percent of Canada's immigrant total (CIC 2001). Between 1991 and 2001, Sri Lanka was the fifth largest source country of immigrants to Canada, after China, India, the Philippines and Hong Kong (see Table 4). In the refugee category, Sri Lanka ranked second between 1998 and 2000 (see Table 5) and was the largest refugee-sending country in 1995. Toronto has been the destination for the vast majority of these immigrants, who comprised the fourth largest immigrant group to that city in 2000 (see Table 6).

The relative importance of the Sri Lankan immigrant group appears to be growing. For a country of less than 19 million people, it is remarkable that Sri Lanka compares with the much more highly populated countries of China, India, Pakistan and the United States as a major sending country to Canada. Between 1992 and 1999, Sri Lanka was the leading source country of refugee claims to Canada (U.S. Committee for Refugees 1993, 1994, 1995, 1996, 1997, 1998, 1999, 2000). Because Canada's inland refugee determination system is not restricted by targets or administrative limits,

Table 5

Refugees to Canada by top ten source countries, 2000

\begin{tabular}{|c|c|c|c|c|c|c|c|c|c|}
\hline \multirow[b]{2}{*}{ Country } & \multicolumn{3}{|c|}{1998} & \multicolumn{3}{|c|}{1999} & \multicolumn{3}{|c|}{2000} \\
\hline & $\#$ & $\%$ & Rank & $\#$ & $\%$ & Rank & $\#$ & $\%$ & Rank \\
\hline Yugoslavia & 559 & 2.45 & 14 & 629 & 2.58 & 13 & 3,831 & 12.75 & 1 \\
\hline Sri Lanka & 2,132 & 9.34 & 2 & 2,611 & 10.70 & 2 & 3,234 & 10.76 & 2 \\
\hline Afghanistan & 1,354 & 5.93 & 4 & 1,816 & 7.45 & 3 & 2,537 & 8.44 & 3 \\
\hline Iran & 1,477 & 6.47 & 3 & 1,447 & 5.93 & 4 & 1,503 & 5.00 & 4 \\
\hline Pakistan & 724 & 3.17 & 9 & 1,088 & 4.46 & 7 & 1,235 & 4.11 & 5 \\
\hline Somalia, D. Republic & 1,195 & 5.23 & 6 & 1,380 & 5.66 & 5 & 1,209 & 4.02 & 6 \\
\hline India & 853 & 3.74 & 8 & 697 & 2.86 & 10 & 1,107 & 3.68 & 7 \\
\hline Iraq & 947 & 4.15 & 7 & 915 & 3.75 & 8 & 982 & 3.27 & 8 \\
\hline Republic of Zaire & 609 & 2.67 & 11 & 696 & 2.85 & 11 & 947 & 3.15 & 9 \\
\hline Bosnia-Herzegovina & 3,590 & 15.72 & 1 & 2,698 & 11.06 & 1 & 839 & 2.79 & 10 \\
\hline
\end{tabular}

SOURCE: CIC (2001). 
Table 6

Immigration to Toronto by top ten source countries, 2000

\begin{tabular}{|c|c|c|c|c|c|c|c|c|c|}
\hline \multirow[b]{2}{*}{ Countriy } & \multicolumn{3}{|c|}{1998} & \multicolumn{3}{|c|}{1999} & \multicolumn{3}{|c|}{2000} \\
\hline & $\#$ & $\%$ & Rank & $\#$ & $\%$ & Rank & $\#$ & $\%$ & Rank \\
\hline China, People's Republic & 8,757 & 11.47 & 1 & 13,696 & 16.22 & 1 & 18,305 & 16.94 & 1 \\
\hline India & 7,484 & 9.80 & 2 & 9,126 & 10.81 & 2 & 15,600 & 14.44 & 2 \\
\hline Pakistan & 5,885 & 7.71 & 3 & 6,512 & 7.71 & 3 & 10,478 & 9.70 & 3 \\
\hline Sri Lanka & 2,626 & 3.44 & 8 & 3,590 & 4.25 & 4 & 4,142 & 3.83 & 4 \\
\hline The Philippines & 3,087 & 4.04 & 6 & 3,287 & 3.89 & 5 & 3,909 & 3.62 & 5 \\
\hline Korea, Republic of & 1,699 & 2.22 & 10 & 2,998 & 3.55 & 7 & 3,457 & 3.20 & 6 \\
\hline Iran & 3,715 & 4.86 & 4 & 3,133 & 3.71 & 6 & 2,983 & 2.76 & 7 \\
\hline United Arab Emirates & 1,324 & 1.73 & 14 & 1,221 & 1.45 & 16 & 2,214 & 2.05 & 8 \\
\hline Russia & 2,690 & 3.52 & 7 & 2,263 & 2.68 & 8 & 2,126 & 1.97 & 9 \\
\hline Jamaica & 1,868 & 2.45 & 9 & 1,984 & 2.35 & 9 & 2,025 & 1.87 & 10 \\
\hline
\end{tabular}

SOURCE: CIC (2001).

any person who arrives at a Canadian port of entry has the right to claim refugee status. This has clearly proven the most suitable category of migrant status for Sri Lankan Tamils. Approval rates have been comparatively high, with 80 percent of claims heard approved in 1999 and 77 percent in 2000 (U.S. Committee for Refugees 2000, 2001). In contrast, the United States has maintained strong relations with the government of Sri Lanka (Wayland 2002) and has officially declared the LTTE a terrorist group since 1997. The United States hosts about 40,000 Sri Lankan Tamils-a fraction of those in Canada, both in terms of absolute numbers and as a proportion of the population (Sriskandarajah 2002).

Many Sri Lankans-particularly Tamils-are leaving or have left their country because of the conflict. In such cases, destinations may be not so much a question of choice as a question of where family relations are based and, hence, where sponsorship opportunities exist, or where governments allow access to asylum hearings through legislation and policies. Canada maintains a large immigration program, significant networks of Sri Lankans in diaspora and comparatively generous refugee legislation and adjudication policies. Allowances to facilitate the additional processing of Sri Lankan Tamil asylum-seekers in the late 1980 s contributed to the growth of the diaspora in Canada (interview C).

Sri Lanka is also objectively a good source of immigrants based on its population's education levels, related skills and official language ability. ${ }^{16}$ It fares far better than its South Asian peers in terms of literacy (91.6 percent), longevity (79 years) and general education levels (UNDP 2002). While more research on the quality and extent of migration between the two countries needs to be done, the significance and momentum of migration is clear.

\section{Concluding Connections}

I will just say that large-scale international migrations are embedded in complex economic, social and ethnic networks; highly conditioned and structured, they are by no means a free-for-all. Reality thus belies the popular dramatic images of massive invasion by the poor. Immigration is really more of a management problem than a crisis. (Sassen 1996, 63)

The multiple connections between conflict, aid and migration, traversing the spaces between Canada and Sri Lanka, suggest a distinct geopol-

16 Canada has attracted a number of internationally renowned writers from Sri Lanka, including Michael Ondaatje and Shyam Selvadurai. Interestingly, both writers were/are members of Sri Lankan society who have not always been made to feel welcome at particular times. Ondaatje's family was of Burgher ancestry (a Creole mix of Dutch and Sinhalese cultural backgrounds), a group that was made less welcome after 1956, when the Sri Lanka government introduced a Sinhala-only language restriction for those working in the public sector. Selvadurai is of Tamil background, and despite his family's relative privilege and urban base, they left Sri Lanka because of the 1983 riots. 
itics and geoeconomics of migration. ${ }^{17}$ Transnationalism-including transnational migrationis not simply a theoretical perspective but, as illustrated here, a nexus of social, political and material relationships that blur the centrality of international borders and replace conventional cartographies with maps that chart social, economic and political fields that traverse such borders on an ongoing basis. Transnational economic liberalisation policies comprise these networks, as do international concerns for security in the aftermath of $9 / 11$ and the war on terrorism.

In examining the connections between Sri Lanka and Canada, my goal has been to analyse the relation of aid, economic liberalisation and migration to conflict in Sri Lanka. With the shift to open markets and the influx of foreign aid and loans in the 1970s, patronage relations were maintained and extended based on significant public-sector investment. Such relations infused Sri Lankan politics with particular class and ethnic alliances that have undoubtedly played a role in Sri Lanka's ongoing conflict. Despite various overtures of peace since 1983, no ceasefire or rapprochement has appeared as promising as the current one. The somewhat sudden push for peace is welcome, but it should be scrutinised and monitored to ensure that it is not simply a push to restore profitability to a desperately damaged economy. Peace at any price will do little to restore stability and security to Sri Lanka, and is likely only to hasten the migration of more Sri Lankans to Canada.

\section{References}

AL-ALI, N., BLACK, R. and KOSER K. 2001 'Refugees and transnationalism: the experience of Bosnians and Eritreans in Europe' Journal of Ethnic and Migration Studies 27 (4), 615-634

AMNESTY INTERNATIONAL 2002 'Sri Lanka: Amnesty International proposes new approach to peace process' 29 June http://web. amnesty.org/ai.nsf/Index/ASA370122002?OpenDocument\&of $=$ COUNTRIES $\backslash S R I+$ LANKA (last accessed 18 July 2003)

ANDERSSEN, E. 2003 'Immigration shifts population kaleidoscope' Globe and Mail 22 January

17 This term is broader than 'geopolitics of mobility', which I have used in earlier analyses of refugee movements (Hyndman 1997). The geopolitics of mobility is, however, relevant here, in that class and gender shape a migrant's prospects of leaving her/his country. Such relations shape whether a person displaced by the war will end up in a government-run welfare centre in Vavuniya, a camp or relative's home in India or a suburb of Toronto.
ARULIAH, A. 1994 'Accepted on compassionate grounds: an admission profile of Tamil immigrants in Canada' Refuge 14 (4), 10-14

athukorala, P. and Jayasuriya, s. 1994 Macroeconomic Policies, Crises and Growth in Sri Lanka, 1969-90 (Washington, DC: The World Bank)

BAILEY, A., WRIGHT, R.A. MOUNTZ, A. and MIYARES, 1.M. 2002 '(Re)producing Salvadoran transnational geographies' Annals of the Association of American Geographers 92 (1), 125-144

BASCH, L., GLICK SCHILLR, N. and SZANTON BLANC, c. 1994 Nations Unbound: Transnational Projects, Postcolonial Predicaments and Deterritorialized Nation-States (New York: Routledge)

BEL, S. 2000 'Sri Lanka's civil war and the Canadian connection' The National Post 3 June http://www.globeandmail.ca

- 2001 'Ottawa won't renew funding of Tamil society' National Post 3 December http://www.nationalpost.com

BOUTWELL, J., and KLARE M.T. 2000 'A scourge of small arms' Scientific American June, 47-55

BRUN, C. 2002 'Finding a place: local integration and protracted displacement in Sri Lanka' Dr. Polit. thesis, Department of Geography, Norwegian University of Science and Technology, Trondheim

CANADIAN INTERNATIONAL DEVELOPMENT AGENCY (CIDA) 2001 'Strengthening aid effectiveness' Policy paper for consultation, February

- 2002 Canada Making a Difference in the World: A Policy on Strengthening Aid Effectiveness September (Hull: Minister of Public Works and Government Services)

-. n.d. 'CIDA's program in Sri Lanka' CIDA briefing paper

CANADIAN SECURITY INTELLIGENCE SERVICE (CSIS) n.d. 'Liberation Tigers of Tamil Eelam (LTTE)' Open sources brief, unclassified

CARDOSO, F.H. and FALETTO E. 1979 Dependency and Development in Latin America (Berkeley: University of California Press)

CHERAN, R. 2000 'Changing formations: Tamil nationalism and national liberation in Sri Lanka and the diaspora' Ph.D. dissertation, Department of Sociology, York University, Toronto

CITIZENSHIP AND IMMIGRATION CANADA (CIC) 1996 'Facts and figures 1996: immigration overview' http://www.cic.gc.ca/english/pub/ 1996stats.pdf

- 2001 Facts and Figures 2000: Immigration Overview (Ottawa: Ministry of Public Works and Government Services Canada)

COLOMBO PLAN 2001 http://www.colombo-plan.org (last accessed 18 July 2003)

DE ALWIS, M 1995. 'Gender, politics and the "respectable lady"' in Unmaking the Nation: The Politics of Identity and History in Modern Sri Lanka, ed P. Jeganathan and Q. Ismail (Colombo: Social Scientists' Association) 137-157

-. Forthcoming "The "purity" of displacement and the reterritorialization of longing: Muslim women refugees in northwestern Sri Lanka' in Sites of Violence: Feminist Politics in Conflict Zones, ed W. Giles and J. Hyndman (Berkeley: University of California Press)

DEALWIS, M. and HYNDMAN J. 2002 Capacity-Building in Conflict Zones: $A$ Feminist Analysis of Humanitarian Assistance in Sri Lanka (Colombo: International Centre for Ethnic Studies)

DEBRIX, F. 1998 'Deterritorialised territories, borderless borders: the new geography of medical assistance' Third World Quarterly $19(5), 827-846$

DEPARTMENT OF CENSUS AND STATISTICS, SRI LANKA 2001 'Value and percentage of exports by country of destination 1995-97' http://www.lk/ census/Documents/Trade.htm

DUFFIELD, M. 1996 'The symphony of the damned: racial discourse, complex political emergencies and humanitarian aid' Disasters 20 (3), 173-193 
ECONOMIST 2000 'Sri Lanka: the war the world is missing' 357 (8191), 27-32

FAIST, T. 1999 Transnationalism in International Migration: Implications for the Study of Citizenship and Culture Working Paper WPTC 99-08 http://www.transcomm.ox.ac.uk/working\%20papers/ faist.pdf (last accessed 18 July 2003)

GEORGE, C. 2001 'CIDA programming in Nepal, India, and Sri Lanka' Public address at Canadian International Development Agency's Vancouver office, 16 March

GLOBE AND MAIL 2002a 'Sri Lankan rivals hold "constructive" meeting' 25 November

- 2002b 'Won't rule out violence, Tamil Tigers warn' 26 November

GOODHAND, J. and D. HULME. 1999 'Understanding conflict and peacebuilding in the new world disorder' Third World Quarterly 20 (1), 13-26

GOVERNMENT OF SRI LANKA 2002 'Highlights of the budget 2003' Minister of Finance http://www.eureka.lk/fpea/budget2003.htm (last accessed 18 July 2003)

GUNASINGHE, N. 1984 'The open economy and its impact on ethnic relations in Sri Lanka' in Sri Lanka: The Ethnic Conflict, Myths, Realities and Perspectives (New Delhi: Committee for Rationale Development)

-. 1987 'Ethnic conflict in Sri Lanka: perceptions and solutions' in Facets of Ethnicity in Sri Lanka, ed C. Abeysekera and N. Gunasinghe (Colombo: Social Scientists Association) 61-71

HUMAN RIGHTS WATCH 2002 'Rights safeguards key to Sri Lanka peace' New york http://www.hrw.org/press/2002/07/Srilankapeace.htm (last accessed I August 2003)

HYNDMAN, J. 1997 'Border crossings' Antipode 29 (2), 149-176

- 2000 Managing Displacement: Refugees and the Politics of Humanitarianism (Minneapolis: University of Minnesota Press)

HYNDMAN, J, and WALTON-ROBERTS, M. 2000 'Interrogating borders: a transnational approach to refugee research in Vancouver' The Canadian Geographer 44 (3), 244-258

INDUSTRY CANADA 2001 'Canadian trade with Sri Lanka' Trade Data Online Industry Canada, 28 March http://strategis.ic.gc.ca/ sc_mrkti/tdst/engdoc/tr_homep.html (last accessed 18 July 2003); http://www.asiapacific.ca/data/trade/general_dataset l_ srilanka.cfm (last accessed 18 July 2003)

JANSZ, F. 2001 'Hand grenade attack on NGO in Colombo' LacNet News Service 31 January

Jayawardena, x. 1990 Ethnic and Class Conflicts in Sri Lanka: Some Aspects of Sinhala Buddhist Consciousness Over the Past 100 Years (Colombo: Sanjwa Books)

JEGANATHAN, P. and ISMAIL \& 1995 'Introduction: unmaking the nation' in Unmaking the Nation: The Politics of Identity and History in Modern Sri Lanka, ed P. Jeganathan and Q. Ismail (Colombo: Social Scientists' Association) 2-9

KAITHA, P. 1996 'Banker, Tiger, soldier, spy' Maclean's 109 (32), 28-32

KNOX, P. 2002 'Sri Lanka peace deal forged on Canada's federal model' The Globe and Mail 6 December, $\mathrm{Al}$

LANG, s. 1997 'The NGOization of feminism: institutionalization and institution-building within the German women's movements' in Transitions, Environments, Translations: Feminisms in Inter national Politics, ed C. Kaplan, D. Keates and J. W. Scott (New York: Routledge) 101-120

MACRAE, J. and LEADER N. 2000 Shifting Sands: The Search for 'Coherence' Between Political and Humanitarian Responses to Complex Emergencies Humanitarian Policy Group Report 8 (London: Overseas Development Institute)

MASSEY, D. 1991. 'A global sense of place' Marxism Today June, 24--29
- 1993 'Power-geometry and a progressive sense of place' in Mapping the Futures: Local Cultures, Global Change, ed J. Bird, B. Curtis, T. Putnam, G. Robertson and L. Tickner (New York: Routledge) 59-69

maunaGuru, s. 1995 'Gendering Tamil nationalism: the construction of "woman" in projects of protest and control' in Unmaking the Nation: The Politics of Identity and History in Modern Sri Lanka, ed P. Jeganthan and Q. Ismail (Colombo: Social Scientists' Association) 158-175

MCDOWELl, C. 1996 A Tamil Diaspora: Sri Lankan Migration, Settlement and Politics in Switzerland (Providence: Bergahn Books)

MCMICHAEL, P. 1996 Development and Social Change: A Global Perspective (Thousand Oaks, CA: Pine Forge Press)

mittelman, J.H. 1988 Out from Underdevelopment: Prospects for the Third World (Basingstoke: Macmillan Press)

MONGIA, R.v. 1999 'Race, nationality, mobility: a history of the passport' Public Culture 11 (3), 527-556

MOORE, M. 1990 'Economic liberalization versus political pluralism in Sri Lanka?' Modern Asian Studies 24 (2), 341-383

MORRIS, N. 1995 'The Canadian connection: Sri Lanka moves to crush Tamil rebels at home and abroad' Maclean's 27, 28-29

MOUNTZ, A. and WRIGHT, R. 1996 'Daily life in the transnational migrant community of San Agustin, Oaxaca and Poughkeepsie, New York' Diaspora 5 (3), 403-428

MUNASINGHEGE, s. 2000 'CSIS warned Ottawa of terror fronts' The Daily News 11 December http://www.nytimes.com

NATIONAL PEACE COUNCIL 2001 Extract from 'The human cost of war' The Daily News 21 April

ONG, A. 1999 Flexible Citizenship: The Cultural Logics of Transnationality (Durham, NC: Duke University Press)

PERERA, J. 2001 'Elite voices and realities in northeast' The Daily News 9 April

-. 2002 'The minimum standard for Thai talks' Unpublished article, September

REFUGEE COUNCIL 2002 Sri Lanka: Return to Uncertainty Sri Lanka Project, London, July http://www.refugeecouncil.org.uk/ downloads/rc_reports/srilanka_uncertainty.pdf (last accessed 18 July 2003)

REUTERS 1999a 'UNHCR funds for war-affected people in Sri Lanka' 15 February

—. 1999b 'Impasse on supply route to northern Sri Lanka' LacNet news service, 15 July

Rostow, w. w. 1960 The Stages of Economic Growth: A Non-Communist Manifesto (Cambridge, U.K.: University Press)

SASSEN, s. 1993. 'Rethinking immigration' Lusitania: A Journal of Reflection and Oceanography 5, 97-102

- 1996 Losing Control: Sovereignty in an Age of Globalization (New York: Columbia University Press)

SENGUPTA, S. 2000 'Canada's Tamils work for a homeland from afar' The New York Times 16 July

SIVANANDAN, A. 1990 Communities of Resistance: Writing on Black Struggles for Socialism (New York: Verso)

SPENCER, J., ed. 1990 Sri Lanka: History and the Roots of Conflict (New York: Routledge)

SRISKANDARAJAH, D. 2002 'The migration-development nexus: Sri Lanka case study' Paper prepared for the Centre for Development Research study 'Migration-Development Links: Evidence and Policy Options', Magdalen College, Oxford, UK

STOKKE, к. 1998 'Sinhalese and Tamil nationalism as post-colonial projects from "above”, 1948-1983' Political Geography 17 (1) 83-113

SURYANARAYAN, v. 2001 'Land of the displaced' Frontline 18 (12) 
SWAMY, M.R.N. 1996 Tigers of Lanka: From Boys to Guerrillas 2d edition (Colombo: Vijitha Yapa Bookshop)

THERIEN, J-P., and LLOYD C. 2000 'Development assistance on the brink' Third World Quarterly 21 (1), 21-38

TiRuChelvaM, N. 1996 'Sri Lanka's ethnic conflict and preventive action: the role of NGOs' in Vigilance and Vengeance: NGOs Preventing Ethnic Conflict in Divided Societies, ed R. Rotberg (Washington, DC: Brookings Institution) 147-164

TORONTO STAR 200I 'Canadian envoy in Sri Lanka meets Tamil Tiger rebel leader' 4 May

UNITED NATIONS DEVELOPMENT FUND (UNDP) 2001 Human Development Report 2001: Making New Technologies Work for Human Development http://www.undp.org/hdr200I/back.pdf (last accessed 18 July 2003)

- 2002 Human Development Report 2002: Deepening Democracy in a Fragmented World http://hdr.undp.org/currentHDR_E (last accessed 18 July 2003)

UNIVERSITY TEACHERS FOR HUMAN RIGHTS, JAFFNA (UTHR [J]) 1999 'The tragedy of Wanni civilians and total militarisation' The Island 30 May, 10

- 2002a Towards a Totalitarian Peace: The Human Rights Dilemma Special Report no. 13, 10 May http://www.uthr.org/ SpecialReports/spreport 13.htm (last accessed 18 July 2003)

—. 2002b "The cost of "peace" and the dividends of war: Sri Lanka's Nordic winter?' Information Bulletin 3, 3 December http:// www.uthr.org/bulletins/bul30.htm (last accessed 18 July 2003)

U.S. COMMITTEE FOR REFUGEES 1992 World Refugee Survey 1992 (Washing ton, DC: American Council for Nationalities Service)

—. 1993 World Refugee Survey 1993 (Washington, DC: American Council for Nationalities Service)

-. 1994 World Refugee Survey 1994 (Washington, DC: Immigration and Refugee Service of America)

-. 1995 World Refugee Survey 1995 (Washington, DC: Immigration and Refugee Service of America)

—. 1996 World Refugee Survey 1996 (Washington, DC: Immigration and Refugee Service of America)

—. 1997 World Refugee Survey 1997 (Washington, DC: Immigration and Refugee Service of America)

—. 1998 World Refugee Survey 1998 (Washington, DC: Immigration and Refugee Service of America)
—. 1999 World Refugee Survey 1999 (Washington, DC: Immigration and Refugee Service of America)

-. 2000 World Refugee Survey 2000 (Washington, DC: Immigration and Refugee Service of America)

- 2001 World Refugee Survey 2001 (Washington, DC: Immigration and Refugee Service of America)

VAITHEESPARA, R. 1999 'Tamils' in Encyclopaedia of Canada's Peoples, ed P.M. Magosci (Toronto: University of Toronto Press) 1247-1254

VAN BRABANT, K. 1997 The Coordination of Humanitarian Action: The Case of Sri Lanka (London: Overseas Development Institute)

WAYLAND, $s$. Forthcoming 'Nationalist networks and transnational opportunities: the Sri Lankan Tamil diaspora' Review of International Studies

WORLD BANK 1998 Assessing Aid: What Works, What Doesn't and Why? (New York: Oxford University)

zUKowsky, J. 2001 Vice president, Canadian Partnership Branch, Canadian International Development Agency; public address, Vancouver, 3 May

\section{Interviews}

Interview A: CIDA manager, 11 June 2002, Ottawa. Interview B: CIDA manager, 13 June 2002, Ottawa Interview C: Canadian diplomat, 17 July 2002, Colombo

Interview D: Department for International Development consultant, 12 July 2002, Colombo

Interview E: Department for International Development diplomat, 15 July 2002, Colombo

Interview F: Canadian diplomat, 17 July 2002, Colombo Interview G: CIDA representative, 12 July 2002, Colombo Interview H: Sri Lankan academic and activist, 23 July 2002, Colombo

Interview I: Sri Lankan academic and activist, 24 July 2002 Colombo 